\title{
The relationship between protein changes in porcine longissimus muscle at different courses of meat tenderisation
}

\author{
Bożena Grześ $^{1} \cdot$ Edward Pospiech $^{1} \cdot$ Ewa Iwańska $^{1} \cdot$ Beata Mikołajczak $^{1} \cdot$ \\ Andrzej Łyczyński ${ }^{2}$ Maria Koćwin-Podsiadła ${ }^{3}$ Elżbieta Krzęcio-Niczyporuk ${ }^{4}$
}

Received: 10 February 2017 / Revised: 18 April 2017 / Accepted: 6 May 2017 / Published online: 23 May 2017

(C) The Author(s) 2017. This article is an open access publication

\begin{abstract}
Among many factors affecting meat tenderness, a special role is attributed to proteins. The aim of this study was to analyse relationships between the tenderness of meat and changes in the abundance of muscle tissue and centrifugal drip proteins as well as in a value of the simple assessment criteria of the glycolysis process in porcine longissimus thoracis et lumborum muscles. All of them were used for describing conditions associated with tenderisation process and predicting tenderness. For analysis of protein changes in the muscle tissue ( $45 \mathrm{~min}, 48$ and $144 \mathrm{~h} \mathrm{pm}$ ) and in its centrifugal drip (48 and $144 \mathrm{~h} \mathrm{pm}$ ), SDS-PAGE technique was applied. The progress of glycolysis was evaluated on the basis of $\mathrm{pH}$ value as well as the electrical conductivity (EC) measurements. Warner-Bratzler shear force assessment (48 and $144 \mathrm{~h} \mathrm{pm}$ ) was involved for the evaluation of tenderness. Comparisons concerned four groups of muscles characterised by different courses of tenderisation. The study showed that proteolysis was closely related to the process of glycolysis in muscles which was linked with genotype of pigs. The single correlations between protein changes and meat tenderness varied in the selected groups of muscles. It was possible to make very precise predictions
\end{abstract}

Bożena Grześ

bgrzes@up.poznan.pl

1 Institute of Meat Technology, Poznań University of Life Sciences, Wojska Polskiego 28, 60-637 Poznań, Poland

2 Department of Animal Breeding and Product Quality Assessment, Poznań University of Life Sciences, Wojska Polskiego 28, 60-637 Poznań, Poland

3 Department of Pigs Breeding and Meat Quality Evaluation, Siedlce University of Natural Sciences and Humanities, Prusa 14, 08-110 Siedlce, Poland

4 Institute of Health Sciences, Siedlce University of Natural Sciences and Humanities, Prusa 14, 08-110 Siedlce, Poland of the meat tenderness using canonical correlation analysis. Based on the percentage participation of the selected muscle tissue and centrifugal drip proteins and measurements of $\mathrm{pH}$ and $\mathrm{EC}$ at specified time $\mathrm{pm}$ it was possible to predict tenderness with a very high probability, even $89 \%$.

Keywords Pork · Proteins · Tenderness (WBSF) . Electrophoresis (SDS-PAGE) · Pork quality indicators

\section{Introduction}

Rapid development of proteomics involves the application of various electrophoretic techniques $[12,14,52$, 55], which allow the identification of many proteins with respect to their properties. It leads to better understanding of the causes and consequences of the phenomena influencing the quality of meat, especially its tenderness $[15,20$, $22,31,32,35,40,47,51]$.

Tenderness belongs to the most important quality parameters of meat, which is especially important by its culinary use. It is a prerequisite of all consumers independent of their age. Usually the tenderisation process is described as the result of protein changes which take place during storage $[2,4,9,10,29,30,36,42]$. It is evident from literature data that the rate of muscle protein degradation depends on a number of factors, such as the age of animals [21], their genotype [11, 24, 27, 43, 45] and meatiness [38, 50] as well as the proximate composition of muscles [6-8, 34, 41], being the most important ones. These changes can be associated with breeding and rearing conditions [18, 27, 54]. Usually pork can be tenderised after 5-6 days of cold storage. However, in some cases, pork is already tender after 2 days of storage, but in other situations it is tough even after 1 week of ageing [17]. 
The rate and extent of post-mortem (pm) changes in proteins also depends on the character of carbohydrate transformation. They are strictly connected with the conversion of muscles into meat and its ageing. The course of glycolysis determines the final $\mathrm{pH}$ value, which, in consequence, affects the culinary and technological quality of meat [28, $56]$, the scale of protein proteolysis $[22,30,56]$ and the ultimate tenderness of meat $[20,25,51]$.

Myofibrillar proteins are the most important fraction of proteins. Products of their degradation can be found in the centrifugal drip from meat $[13,37,48]$. Therefore, these two groups of proteins were subjected to analyses in this study.

Taking into account all the above data the aim of this study was to analyse changes occurring in proteins of the longissimus muscles and their centrifugal drip and to observe the speed of glycolysis in muscles, all from pigs which were assigned to different genotypes in regard to $R Y R l$ gene, for more precise description of meat process tenderisation. As a tool in this study it was used canonical data analysis. It allows better explaining relationships between various groups of features related to different courses of meat acidification, proteolysis and meat tenderisation.

\section{Materials and methods}

\section{Characteristic of pigs and their meat quality evaluation}

The experimental material was the longissimus thoracis et lumborum (LTL) muscle from 24 pigs of a known RYRI genotype (TT-homozygous negative, CT-heterozygous, $\mathrm{CC}$-homozygous positive) as well as rearing and feeding conditions. Pigs were selected from a total number of 165 fatteners. They were slaughtered at a weight of about $110 \mathrm{~kg}$. Samples were selected on the basis of measurement of the shear force value and they were allocated to four groups $(\mathrm{A}, \mathrm{B}, \mathrm{C}, \mathrm{D})$ differing in the course of the tenderisation process. Muscles assigned to groups $\mathrm{A}$ and B originated from fatteners of Line 890 (Line $990 \times$ Pietrain). Samples belonging to group $\mathrm{C}$ were hybrids of Landrace $\times$ Duroc $(L \times$ Dur $)$ descent, and samples from pigs in group D were hybrids of the (Landrace $\times$ Yorkshire $) \times$ Duroc $[(\mathrm{L} \times \mathrm{Y}) \times$ Dur]. Genotypes of analyzed animals in terms of locus RYRI were identified using PCRRFLP (Fujii et al. 1991). All fatteners from group A were CT heterozygotes. Similar genotype expressed half of pigs in the group B, but the second part of pigs in this group was susceptible to stress (TT homozygotes). Pigs belonged to the remaining groups $(\mathrm{C}$ and $\mathrm{D})$ were resistant to stress (CC homozygotes). However, similar to the group B the speed of glycolysis in their muscles pm was varied.
The quality of all muscles was assessed on the basis of $\mathrm{pH}_{1}(45 \mathrm{~min} \mathrm{pm})$ and $\mathrm{pH}_{2}(24 \mathrm{~h} \mathrm{pm})$ measurements as well as the electrical conductivity (EC) evaluated at 1.5 (EC1) and 24 (EC2) h pm [28, 33].

\section{Samples for electrophoresis}

Samples were collected from LTL muscles three times. In order to conduct measurements immediately after slaughter $\left(45^{\prime} \mathrm{pm}\right)$, small samples (about $5 \mathrm{~g}$ ) were cut out of the carcasses at the level of the last rib and wrapped in aluminium foil. Next, they were quickly frozen in liquid nitrogen and stored at $-80{ }^{\circ} \mathrm{C}$ until analysis. Samples for electrophoresis 48 and $144 \mathrm{~h} \mathrm{pm}$ were collected in a similar way. However, before the preparation of samples bigger cuts of longissimus muscle (around $0.5 \mathrm{~kg}$ ) were collected from chilled carcasses $24 \mathrm{~h} \mathrm{pm}$. Then, they were divided into two equal parts for analysis 48 and $144 \mathrm{~h} \mathrm{pm}$. Next, they were vacuum packed and stored at $2-4{ }^{\circ} \mathrm{C}$ until the target term of the study. These muscles were used for all other investigations related to the electrophoresis of proteins in meat and centrifugal drip from it, and evaluation of tenderness.

Samples of the muscle tissue for electrophoretic analysis were collected $45 \mathrm{~min}, 48$ and $144 \mathrm{~h}$ after slaughter, while centrifugal drip samples- 48 and $144 \mathrm{~h} \mathrm{pm}$. The centrifugal drip was obtained by centrifugation of $6 \mathrm{~g}$ of comminuted muscle tissue (for $15 \mathrm{~min}$ at $15,000 \times g$ at $2{ }^{\circ} \mathrm{C}$ ) in a Sigma 3K30 centrifuge [19].

\section{SDS-PAGE and western blotting}

Electrophoretic separations of the muscle tissue and centrifugal drip proteins were carried out on $15 \%$ polyacrylamide gels (199:1 ratio of acrylamide to $N, N^{\prime}$ methylenebisacrylamide) with the addition of $8 \mathrm{M}$ urea [50]. Separated proteins underwent quantitative evaluation with the Image Master ${ }^{\circledR}$ VCR set of the Pharmacia Company and Image Master ${ }^{\circledR} 1 \mathrm{D}$ program. The selected muscle tissue and centrifugal drip proteins such as titin, myosin (MHC), troponin $\mathrm{T}$ (Tn-T) and glyceraldehyde3-phosphate dehydrogenase (GAPDH) were identified by means of the western blotting method described by Fritz and Greaser [14]. Primary monoclonal antibodies used in this study, including mouse anti-titin (clone 9D10), came from the collection of the Meat Science and Muscle Biology Laboratory of the University of Wisconsin (USA). Mouse anti-troponin T (clone JLT12) and mouse anti-GAPDH (clone GAPDH-71.1) came from Sigma-Aldrich. Mouse anti-myosin (clone MF 20) was purchased from the Developmental Studies Hybridoma Bank at the University of Iowa (USA). Alkaline phosphatase conjugated anti-mouse IgG was a secondary antibody purchased from Sigma-Aldrich. The basis 
of proteins selection for the identification of advancement of proteolysis using the western-blotting was the qualitative and quantitative computer assisted image analysis of gels. Special attention was paid on these proteins bands, which changed their intensity and their abundance could be linked with the progress of meat tenderisation.

\section{WBSF measurements}

In order to determine the Warner-Bratzler shear force (WBSF) values, 25-mm thick meat slices weighing about $120 \mathrm{~g}$ were prepared. They were heated in a Rational Combi convection oven in hot air at $160{ }^{\circ} \mathrm{C}$ for about $15 \mathrm{~min}$ until the temperature inside them was $72{ }^{\circ} \mathrm{C}$ [17]. The WBSF values after 48 and $144 \mathrm{~h} \mathrm{pm}$ were measured perpendicularly to the direction of muscle fibres, using an Instron Universal Testing Machine, model 1140 , equipped with a Warner-Bratzler device [17].

\section{Groups of different courses of tenderisation process}

The experimental muscles were divided into four groups of different courses of tenderisation according to shear force values: A-meat remaining tough during the entire $144 \mathrm{~h}$ of pm storage; B-meat characterised by typical tenderisation process, i.e. tough after $48 \mathrm{pm}$ and tender after $144 \mathrm{~h}$ of pm storage; C-tender or relatively tender meat at both of the aforementioned terms of examination; D-toughest meat 48 and most tender-144 h pm. Meat was considered as tough if the shear force by its cutting exceeded $60 \mathrm{~N} / \mathrm{cm}^{2}$ and tender when its shear force was lower than $40 \mathrm{~N} / \mathrm{cm}^{2}[3,32]$.

\section{Statistical analysis}

Analysis of variance as well as linear and canonical correlation was conducted by means of the Statistica 10.0 PL [49] software to determine differences or relationships between the groups of muscles in terms of their properties. Special attention was paid to the canonical correlation analysis. This method, in relation to linear correlation analysis, allows estimating relationships between two sets of variables. In comparison with multiple regression, in which there is only one dependent variable and multiple independent variables and a linear combination of independent variables is formed, the objective of this method is to find a linear combination for each set of variables. In canonical correlation there is more than one dependent variable and linear combinations are constructed from both dependent and independent variables with the maximum correlation between them. Therefore, canonical correlation analysis produces richer information than multiple regression analysis [26].

\section{Results and discussion}

\section{Assessment of meat quality}

On the basis of the $\mathrm{pH}$ values $\left(\mathrm{pH}_{1} \& \mathrm{pH}_{2}\right)$ and $\mathrm{EC}(\mathrm{EC} 1$ \& $\mathrm{EC} 2)$ measurements it was stated that the samples from all groups of pigs (A, B, C and D) were basically normal quality (RFN). Despite the fact that the quality of the muscles assessed using these criteria was generally accepted, they differed in the rate of glycolysis, as can be seen in Table 1 . The highest $\mathrm{pH}_{1}$ values were observed in muscles of pigs with CC genotype (groups $\mathrm{C}$ and D) and the lowest in the group A. Pigs belonging to group A were carriers of $R Y R I$ gene. It is necessary to mention that the differentiation in
Table 1 Changes of $\mathrm{pH}$ and EC values of the muscle tissue during pm storage

\begin{tabular}{|c|c|c|c|c|c|c|}
\hline \multirow[t]{3}{*}{ Group } & \multicolumn{6}{|c|}{ Time of post-mortem } \\
\hline & \multicolumn{4}{|l|}{$\mathrm{pH}$} & \multicolumn{2}{|l|}{$\mathrm{EC}(\mathrm{mS} / \mathrm{cm})$} \\
\hline & $45^{\prime}$ & $24 \mathrm{~h}$ & $48 \mathrm{~h}$ & $144 \mathrm{~h}$ & $1.5 \mathrm{~h}$ & $24 \mathrm{~h}$ \\
\hline A & $6.18 \pm 0.40$ & $5.62^{\mathrm{ab}} \pm 0.11$ & $5.46 \pm 0.05$ & $5.45^{\mathrm{a}} \pm 0.06$ & $4.36^{\mathrm{ab}} \pm 4.45$ & $5.55^{\mathrm{b}} \pm 2.95$ \\
\hline B & $6.45 \pm 0.10$ & $5.76^{\mathrm{b}^{*}} \pm 0.16$ & $5.53 \pm 0.11$ & $5.76^{\mathrm{b}} \pm 0.33$ & $3.53^{\mathrm{abc}} \pm 1.21$ & $4.33^{\mathrm{ab}} \pm 1.21$ \\
\hline $\mathrm{C}$ & $6.53 \pm 0.18$ & $5.55^{\mathrm{a}} \pm 0.09$ & $5.47 \pm 0.06$ & $5.47^{\mathrm{ab}} \pm 0.04$ & $1.77^{\mathrm{a}} \pm 0.23$ & $2.57^{\mathrm{ac}} \pm 0.73$ \\
\hline D & $6.56 \pm 0.15$ & $5.80^{\mathrm{b}} \pm 0.06$ & $5.57 \pm 0.14$ & $5.66^{\mathrm{ab}} \pm 0.13$ & $3.91^{\mathrm{ab}} \pm 0.86$ & $4.12^{\mathrm{ab}} \pm 0.69$ \\
\hline \multicolumn{7}{|c|}{$*,{ }^{\mathrm{a}, \mathrm{b}, \mathrm{c}}$ Means in the same column with different superscripts are significantly different at $p \leq 0.05$} \\
\hline \multicolumn{7}{|c|}{$\mathrm{A}-$ meat remaining tough during the entire $144 \mathrm{~h}$ pm changes } \\
\hline \multicolumn{7}{|c|}{$\begin{array}{l}\text { B-meat characterised by typical tenderisation process, i.e. tough } 48 \mathrm{~h} \mathrm{pm} \text {, and tender after } 144 \mathrm{~h} \mathrm{pm} \mathrm{stor-} \\
\text { age }\end{array}$} \\
\hline \multicolumn{7}{|c|}{$\mathrm{C}$ - tender or relatively tender meat on both aforementioned dates of examination } \\
\hline \multicolumn{7}{|c|}{$\mathrm{D}$-meat toughest $48 \mathrm{~h} \mathrm{pm}$, and most tender $144 \mathrm{~h} \mathrm{pm}$} \\
\hline
\end{tabular}


regard to muscle acidification at this point of measurement between all groups of pigs were not significant. The fastest and the most deepest progress of muscle $\mathrm{pH}$ slope during the first $24 \mathrm{~h} \mathrm{pm}$ was observed in the group C. These changes occurred further throughout the next $24 \mathrm{~h}$ of meat storage. They revealed the lowest values of EC. In spite of some diversity of $\mathrm{pH}$ values $48 \mathrm{pm}$ the differences among all groups were again not significant.

In the Table 2 are presented results of the instrumental evaluation of tenderness performed 48 and $144 \mathrm{~h} \mathrm{pm}$. The highest hardness $48 \mathrm{pm}$ was noted for the muscles from the group D, a the lowest-in the case of the group C. After $144 \mathrm{~h}$ of cold storage of LTL muscles the significant differentiation in tenderness appeared between muscles from the group A and the others. Muscles from the group A were evaluated as the most hard (WBSF $>60 \mathrm{~N} / \mathrm{cm}^{2}$ ). It seems that the allocation of muscles to specific groups of tenderness corresponds to their genetic differentiation.

\section{Assessment of post-mortem changes in muscle tissue proteins}

We used the western blotting method to identify and assess the percentage proportions of the following changes in the muscle tissue: native titin defined as $\mathrm{T} 1[16,50,53]$ with a molecular weight (m.w.) of about $3700 \mathrm{kDa}$ as well as one of its degradation products of about $800 \mathrm{kDa}$. We used the 9D10 anti-titin antibody for immunoblotting against titin. At all terms of analyses the highest proportion of native titin together with its degradation product was found in the muscle tissue from pigs in group A (Table 3). After $48 \mathrm{pm}$ there was a statistically significant difference $(p \leq 0.05)$ in the amount of native titin between tough muscles from group A and tender ones from group C. After $144 \mathrm{~h} \mathrm{pm}$

Table 2 WBSF values of the thoracis et lumborum muscle $\left(\mathrm{N} / \mathrm{cm}^{2}\right)$

\begin{tabular}{lll}
\hline Group & \multicolumn{2}{l}{ WBSF values $\left(\mathrm{N} / \mathrm{cm}^{2}\right)$} \\
\cline { 2 - 3 } & $48 \mathrm{~h}$ & $144 \mathrm{~h}$ \\
\hline A & $73.34^{\mathrm{b}^{*}} \pm 14.14$ & $61.31^{\mathrm{b}} \pm 6.50$ \\
B & $69.30^{\mathrm{b}} \pm 8.50$ & $35.19^{\mathrm{a}} \pm 5.82$ \\
C & $39.42^{\mathrm{a}} \pm 3.93$ & $35.82^{\mathrm{a}} \pm 4.20$ \\
D & $92.92^{\mathrm{c}} \pm 9.23$ & $28.70^{\mathrm{a}} \pm 4.28$ \\
\hline
\end{tabular}

*, ${ }^{\mathrm{a}, \mathrm{b}, \mathrm{c}}$ Means in the same column with different superscripts are significantly different at $p \leq 0.05$

A-meat remaining tough during the entire $144 \mathrm{~h}$ pm changes

$\mathrm{B}$ - meat characterised by typical tenderisation process, i.e. tough $48 \mathrm{~h} \mathrm{pm}$, and tender after $144 \mathrm{~h} \mathrm{pm}$ storage

$\mathrm{C}$ - tender or relatively tender meat on both aforementioned dates of examination

$\mathrm{D}$-meat toughest $48 \mathrm{~h} \mathrm{pm}$, and most tender $144 \mathrm{~h} \mathrm{pm}$
Table 3 Changes in the relative proportion of muscle tissue proteins during aging of pork differed in its tenderisation course $(\%)$

\begin{tabular}{|c|c|c|c|}
\hline \multirow{2}{*}{$\begin{array}{l}\text { Muscle tissue pro- } \\
\text { teins/group }\end{array}$} & \multicolumn{3}{|l|}{ Time of storage } \\
\hline & $45^{\prime}$ & $48 \mathrm{~h}$ & $144 \mathrm{~h}$ \\
\hline \multicolumn{4}{|c|}{ About 3700 kDa (T1) } \\
\hline A & $5.87 \pm 1.12$ & $6.80^{\mathrm{b}} \pm 1.30$ & $7.61^{c} \pm 1.61$ \\
\hline B & $5.36 \pm 1.88$ & $5.53^{\mathrm{ab}} \pm 1.58$ & $5.31^{\mathrm{b}} \pm 1.33$ \\
\hline $\mathrm{C}$ & $4.74 \pm 1.24$ & $5.03^{\mathrm{a}} \pm 1.13$ & $4.96^{\mathrm{a}} \pm 1.43$ \\
\hline $\mathrm{D}$ & $4.72 \pm 1.20$ & $5.45^{\mathrm{ab}} \pm 0.62$ & $5.12^{\mathrm{b}} \pm 1.20$ \\
\hline \multicolumn{4}{|l|}{ About $800 \mathrm{kDa}$} \\
\hline A & $1.60^{b^{*}} \pm 0.42$ & $1.24^{\mathrm{b}} \pm 0.33$ & $0.77^{\mathrm{c}} \pm 0.15$ \\
\hline $\mathrm{B}$ & $1.57^{\mathrm{b}} \pm 0.58$ & $1.07^{\mathrm{c}} \pm 0.48$ & $0.58^{b} \pm 0.19$ \\
\hline $\mathrm{C}$ & $0.99^{\mathrm{a}} \pm 0.40$ & $0.62^{\mathrm{a}} \pm 0.09$ & $0.47^{\mathrm{ab}} \pm 0.16$ \\
\hline $\mathrm{D}$ & $0.87^{\mathrm{a}} \pm 0.21$ & $0.55^{\mathrm{a}} \pm 0.15$ & $0.36^{\mathrm{a}} \pm 0.09$ \\
\hline \multicolumn{4}{|l|}{$>205 \mathrm{kDa}$} \\
\hline A & $8.36^{\mathrm{b}} \pm 0.99$ & $8.99^{\mathrm{c}} \pm 1.21$ & $9.08^{b} \pm 1.43$ \\
\hline $\mathrm{B}$ & $7.55^{\mathrm{ab}} \pm 2.40$ & $7.52^{b c} \pm 1.78$ & $6.19^{\mathrm{a}} \pm 1.39$ \\
\hline $\mathrm{C}$ & $5.74^{\mathrm{a}} \pm 1.26$ & $5.70^{\mathrm{a}} \pm 1.10$ & $5.77^{\mathrm{a}} \pm 1.77$ \\
\hline $\mathrm{D}$ & $5.77^{\mathrm{a}} \pm 1.41$ & $6.46^{\mathrm{ab}} \pm 1.07$ & $5.68^{\mathrm{a}} \pm 1.34$ \\
\hline \multicolumn{4}{|l|}{$205 \mathrm{kDa}$} \\
\hline A & $12.69 \pm 0.77$ & $13.21^{\mathrm{a}} \pm 1.13$ & $13.40^{\mathrm{a}} \pm 1.74$ \\
\hline B & $12.59 \pm 1.31$ & $13.69^{\mathrm{ab}} \pm 1.48$ & $13.16^{\mathrm{a}} \pm 0.79$ \\
\hline $\mathrm{C}$ & $13.27 \pm 1.25$ & $16.26^{\mathrm{c}} \pm 1.71$ & $16.18^{\mathrm{b}} \pm 2.21$ \\
\hline $\mathrm{D}$ & $12.59 \pm 0.99$ & $15.35^{\mathrm{bc}} \pm 1.59$ & $14.77^{\mathrm{ab}} \pm 1.05$ \\
\hline \multicolumn{4}{|l|}{$105 \mathrm{kDa}$} \\
\hline A & $3.37^{b} \pm 0.71$ & $3.62^{b} \pm 0.65$ & $3.53 \pm 0.24$ \\
\hline B & $2.67^{\mathrm{a}} \pm 0.39$ & $2.83^{\mathrm{a}} \pm 0.47$ & $2.58 \pm 0.41$ \\
\hline $\mathrm{C}$ & $2.56^{\mathrm{a}} \pm 0.19$ & $2.76^{\mathrm{a}} \pm 0.36$ & $2.72 \pm 0.33$ \\
\hline $\mathrm{D}$ & $2.72^{\mathrm{a}} \pm 0.31$ & $3.05^{\mathrm{ab}} \pm 0.35$ & $2.91 \pm 0.45$ \\
\hline \multicolumn{4}{|l|}{$38-36 \mathrm{kDa}$} \\
\hline A & $6.21^{\mathrm{a}} \pm 1.27$ & $5.5^{\mathrm{a}} \pm 1.05$ & $5.65 \pm 1.10$ \\
\hline $\mathrm{B}$ & $6.74^{\mathrm{a}} \pm 1.09$ & $5.17^{\mathrm{a}} \pm 1.38$ & $6.19 \pm 0.57$ \\
\hline $\mathrm{C}$ & $8.2^{\mathrm{b}} \pm 0.97$ & $6.86^{\mathrm{b}} \pm 0.94$ & $6.83 \pm 1.04$ \\
\hline $\mathrm{D}$ & $7.31^{\mathrm{ab}} \pm 1.28$ & $6.07^{\mathrm{ab}} \pm 1.00$ & $5.89 \pm 1.43$ \\
\hline
\end{tabular}

*, a, b, c Means in the same column with different superscripts are significantly different at $p \leq 0.05$

A - meat remaining tough during the entire $144 \mathrm{~h}$ pm changes

$\mathrm{B}$-meat characterised by typical tenderisation process, i.e. tough $48 \mathrm{~h} \mathrm{pm}$, and tender after $144 \mathrm{~h} \mathrm{pm}$ storage

$\mathrm{C}$ - tender or relatively tender meat on both aforementioned dates of examination

$\mathrm{D}$-meat toughest $48 \mathrm{~h} \mathrm{pm}$, and most tender $144 \mathrm{~h} \mathrm{pm}$

the highest $(p \leq 0.05)$ amount of T1 was observed in the muscles characterised by the highest shear force value (group A), as compared with the other groups (Table 3). The highest proportion of native titin found in the muscle tissue from group A was probably associated with the genetic background of pigs. They came from experimental fatteners of Line 890, whose muscles exhibited a rapid course of glycolysis pm. Faster glycolysis may limit the 
process of native titin degradation and its liberation from the cytoskeletal structures and it may exert negative influence on tenderness, as indicated in experiments conducted by other researchers [1, 44]. The analysis of correlation in group $\mathrm{A}$ showed a significant negative relationship between the $\mathrm{pH}$ value measured $24 \mathrm{~h} \mathrm{pm}$ and the proportion of $\mathrm{T} 1$ in the tissue 48 and $144 \mathrm{~h} \mathrm{pm}(r=-0.94$ and $-0.82 ; p \leq 0.05$, respectively). As far as group $\mathrm{C}$ is concerned, the value of the correlation coefficient between the percentage of $\mathrm{T} 1$ in the muscle tissue $48 \mathrm{pm}$ and the $\mathrm{pH}$ value 24 and $48 \mathrm{pm}$ amounted to $r=0.83$ and 0.82 , respectively $(p \leq 0.05)$. These data indicate close correlation between native titin degradation and the rate of glycolysis. In all the groups there were statistically significant correlations between tenderness of the muscle tissue and the intensity of the $\mathrm{T} 1$ band 48 and $144 \mathrm{~h} \mathrm{pm}(r=0.57$ and $0.65 ; p \leq 0.05$, respectively). However, the values of correlation were not very high. This indicates that the process of meat tenderisation is relatively significantly associated with the degradation of cytoskeletal proteins. They are a scaffolding for myofibrils, in which titin participates to a considerable extent.

The next band visible on polyacrylamide gel (Fig. 1) was a product of titin (T1) degradation of about $800 \mathrm{kDa}$. Its derivation from titin was confirmed by immunoblotting using the 9D10 anti-titin antibody. Its proportion was the highest $(p \leq 0.05)$ in the tough meat of groups A and B $45 \mathrm{~min}$ and $48 \mathrm{pm}$, amounting to: 1.60 and $1.57 \%$ or 1.24 and $1.07 \%$, respectively. On the other hand, the smallest quantities of this protein were found in tender muscles of groups C and D after $144 \mathrm{~h}$ of cold storage (Table 3).

We observed an increasing tendency in the proportion of the $205 \mathrm{kDa}$ band on electropherogram during meat storage. Investigations conducted by Huff-Lonergan et al. [22] and Taylor et al. [51] on bovine skeletal muscles proved that some titin degradation products may have the same molecular weight as myosin heavy chains (MHC) and this might explain the increased proportion of this band in this study. After $48 \mathrm{pm}$, the $205 \mathrm{kDa}$ protein band proportion was the highest in the muscles of group $\mathrm{C}$, as compared with the tough meat of groups A and B. Following $144 \mathrm{~h} \mathrm{pm}$, the highest amount of the $205 \mathrm{kDa}$ protein was recorded in the muscles of group $\mathrm{C}$, as compared with groups $\mathrm{A}$ and $\mathrm{B}$. Grześ et al. [18] showed that the lesser tenderness of pork from $R Y R I^{T}$ carriers (with the CT and TT genotypes) was related to the greater percentage of MHC isoform type IIb. There was also better tenderness of the bovine longissimus dorsi muscle of four cattle breeds (Polish Holstein-Friesian, Polish Red, Hereford and Limousine). It was characterised by the largest percentage of MHC isoform type IIa as well as the effect of the $\mu$-calpain $(C A P N 1 S)$ gene as a factor determining meat tenderness [24]. Differences in MHC isoforms may also be related to changes in the waterholding capacity of meat [18]. In this case, a larger amount of centrifugal and thermal drip of meat collected from pigs exposed to stress (TT) $144 \mathrm{~h}$ post mortem could have been related, among other things, with an increased content of MHC isoform type IIb [18].
Fig. 1 SDS-PAGE profiles of muscle tissue proteins from pork. Group A-samples from tough meat during the entire $144 \mathrm{~h} \mathrm{pm}$, Group C-samples from tender or relatively tender meat after 48 and $144 \mathrm{~h} \mathrm{pm}$

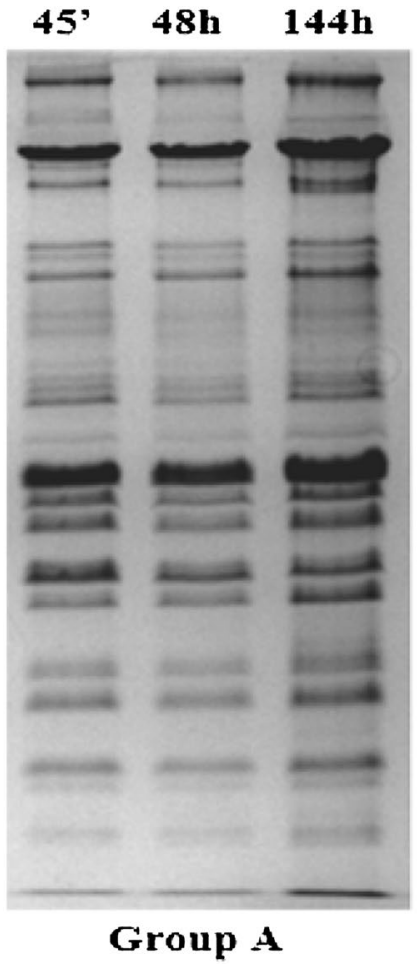


The protein band of $105 \mathrm{kDa}$, was most probably $\alpha$-actinin. It is a factor which cements the $\mathrm{Z}$ disc structure and which is responsible for the sarcomere stability [5]. It is believed that this protein does not undergo degradation but is released from cytoskeletal structures during pm proteolysis [10, 11]. This gradual process of liberation was observed during the course of tenderisation of the four groups of muscles examined. At all terms of study the percentage of this protein was relatively high in tough muscles in group A: $3.37 \%\left(45^{\prime}\right), 3.62 \%(48)$, and $3.53 \%(144 \mathrm{~h})$ as well as in group D (3.0 5\%) 48 pm (Table 3). In most cases the differences between this (group A) and other (B, C and D) groups were statistically significant $(p \leq 0.05)$. Investigations carried out $48 \mathrm{pm}$ showed that the content of this protein was the lowest in group C $(2.76 \%)$ and B $(2.83 \%)$. The correlation analysis for all the groups under study showed a significant relationship between the intensity of the $105 \mathrm{kDa}$ band (48 and $144 \mathrm{~h}$ ) and shear force assessed $144 \mathrm{~h} \mathrm{pm}$ ( $r=0.50$ and $0.54 ; p \leq 0.05$, respectively).

For a long time the rate of troponin $\mathrm{T}(\mathrm{Tn}-\mathrm{T}-\mathrm{m}$.w. of about $38 \mathrm{kDa}$ ) degradation has been considered as an indicator of meat tenderisation processes [42]. The statistical assessment revealed a decrease of about $38 \mathrm{kDa}$ protein band abundance practically in all muscles of the groups under study during their cold storage (Table 3 ). At the first term of examination the percentage of the Tn-T band was statistically significantly higher in the meat of group $\mathrm{C}$ $(8.21 \%)$ than in groups A and B. After 48 pm the proportion of this protein in the muscles of group $\mathrm{C}$ decreased to $6.86 \%$. In comparison with group C, $48 \mathrm{pm}$, the lowest levels of this protein were recorded in groups A and B (5.51 and $5.17 \%$, respectively) ( $p \leq 0.05$ ) (Table 3 ).

\section{Assessment of changes in the proportion of centrifugal drip proteins}

Several studies point out $[13,37,43]$ that changes in myofibrillar proteins can find their reflection in separations of centrifugal drip proteins obtained from the muscle tissue at the same terms. The electrophoretic analysis of centrifugal drip proteins showed increased proportions of bands whose m.w. reached $3700-2400 \mathrm{kDa}$ in all the groups during $144 \mathrm{~h} \mathrm{pm}$ storage. At the first term of investigations $(48 \mathrm{pm})$, the mean proportion values of this protein ranged from 0.83 to $2.00 \%$, while after $144 \mathrm{~h} \mathrm{pm-}$ from 2.05 to $2.71 \%$ (Table 4 ). The presence of titin $\mathrm{T} 1$ and titin T2 (m.w. about $2400 \mathrm{kDa})$ in the fraction of centrifugal drip was confirmed by western blotting using the anti-titin monoclonal antibody 9D10. The increase of its percentage proportion between 48 and $144 \mathrm{~h} \mathrm{pm}$ might indicate that beside probably degradation of this protein its release from muscle cytoskeletal structure took place. As a result of this reaction followed an increase of
Table 4 Changes in the relative proportion of the centrifugal drip proteins from pork differed in its tenderisation $(\%)$

\begin{tabular}{lll}
\hline Centrifugal drip proteins/group & \multicolumn{2}{l}{ Time of storage } \\
\cline { 2 - 3 } & $48 \mathrm{~h}$ & $144 \mathrm{~h}$ \\
\hline $3700-2400 \mathrm{kDa}$ & & \\
$\mathrm{A}$ & $0.91^{\mathrm{a}^{*}} \pm 0.17$ & $2.23 \pm 0.97$ \\
$\mathrm{~B}$ & $1.56^{\mathrm{ab}} \pm 0.78$ & $2.05 \pm 0.76$ \\
$\mathrm{C}$ & $0.83^{\mathrm{a}} \pm 0.22$ & $2.63 \pm 0.73$ \\
$\mathrm{D}$ & $2.00^{\mathrm{b}} \pm 1.10$ & $2.71 \pm 0.87$ \\
153 kDa & & \\
A & $2.93 \pm 0.76$ & $3.45^{\mathrm{a}} \pm 0.68$ \\
B & $2.76 \pm 0.58$ & $2.84^{\mathrm{a}} \pm 0.42$ \\
C & $2.86 \pm 0.90$ & $3.09^{\mathrm{a}} \pm 0.55$ \\
D & $3.01 \pm 0.52$ & $4.24^{\mathrm{b}} \pm 0.29$ \\
$38-36 \mathrm{kDa}$ & & \\
A & & \\
B & $20.55^{\mathrm{c}} \pm 1.88$ & $20.05^{\mathrm{b}} \pm 1.18$ \\
C & $11.70^{\mathrm{a}} \pm 1.05$ & $11.89^{\mathrm{a}} \pm 0.79$ \\
D & $12.76^{\mathrm{a}} \pm 1.99$ & $10.86^{\mathrm{a}} \pm 1.18$ \\
\hline
\end{tabular}

*, ${ }^{\mathrm{a}, \mathrm{b}, \mathrm{c}}$ Means in the same column with different superscripts are significantly different at $p \leq 0.05$

A - meat remaining tough during the entire $144 \mathrm{~h}$ pm changes

$\mathrm{B}$-meat characterised by typical tenderisation process, i.e. tough $48 \mathrm{~h} \mathrm{pm}$, and tender after $144 \mathrm{~h}$ pm storage

$\mathrm{C}$-tender or relatively tender meat on both aforementioned dates of examination

$\mathrm{D}$-meat toughest $48 \mathrm{~h} \mathrm{pm}$, and most tender $144 \mathrm{~h} \mathrm{pm}$

weakening the external cytoskeletal structure, what could foster an improvement of meat tenderness. This phenomenon was probably reflected also by the measurements of the muscle shear force. Its lower values in groups $\mathrm{B}, \mathrm{C}$ and $\mathrm{D}$ in comparison to the group A were noted $144 \mathrm{~h} \mathrm{pm}$ (Table 2). The $\mathrm{T} 1$ degradation with progressing meat aging was observed also in earlier studies [16, 23, 45].

The statistical analysis of the proportion of proteins with m.w. of about $153 \mathrm{kDa}$ revealed an increase in their proportion in the course of storage, although sometimes it was relatively small. At the first term of examination (48 pm), their mean percentage ranged from 2.76 to $3.01 \%$, while after $144 \mathrm{~h} \mathrm{pm-from} 2.84$ to $4.24 \%$. In comparison with the other groups the highest proportion (statistically significant difference) was determined in group $\mathrm{D}$, where the tenderness of muscles was the highest $144 \mathrm{~h} \mathrm{pm}$. The increased proportion of this protein band observed in the drip may have been caused by the liberation of MHC degradation products. This assumption comes from comparisons of our results with the experiments by Sawdy et al. [46]. They used SDS-PAGE and mass spectrometry and identified fragments of similar size. It shows that MHC degradation products can be 
identified in the drip and their presence could be connected with the process of meat tenderisation.

We paid special attention to changes in the proportion of protein in a weight range of $38-36 \mathrm{kDa}$, which was identified as the glyceraldehyde-3-phosphate dehydrogenase (GAPDH with an m.w. of about $37 \mathrm{kDa}$ ) by means of western blotting, using the specific monoclonal antibody (clone GAPDH 71.1). The highest $(p \leq 0.05)$ proportion of this protein band was observed in tough muscles, i.e. in group A-20.55\% (48) and 20.05\% (144 h). The smallest proportion of the protein band at the first term of examination was recorded in drips derived from groups $\mathrm{B}$ and $\mathrm{C}$ (Table 4). In other studies researchers observed that this band disappeared during cold storage of packed meat [39] and simultaneously, the quantity of this protein decreased noticeably in tender muscles [48]. In our study we noted that the amounts of this protein in drips derived from tender muscles in groups B, C and D $144 \mathrm{~h} \mathrm{pm}$ were statistically significantly $(p \leq 0.05)$ lower than in group A (tough meat at both terms). Moreover, we found statistically significant $(p \leq 0.05)$ differences in the proportion of this band in the drip from groups A and D between 48 and $144 \mathrm{~h} \mathrm{pm}$. The correlation analysis for all the experimental groups revealed a significant correlation between the proportion of the 38-36 kDa band on gel from both terms of examination and tenderness determined $144 \mathrm{~h} \mathrm{pm}$ (respectively: $r=0.67$ and $0.87 ; p \leq 0.05$ ). It confirms that the decreased proportion of this protein observed in the drip was associated with the tenderisation process.

\section{Canonical analysis of results}

The obtained results revealed that in some cases, in our study_-groups, changes of single proteins did not fully or with a similar probability described the process of meat tenderisation. Its pattern varied depending on the muscles acidification process and their diverse proteolysis. Because these changes to some extend might be linked to the pigs genotypes we mentioned them. Now, to get deeper or more precise relationships it can be used various methods of the statistical evaluations [33, 38, 51]. Our special attention was turned to the canonical correlation analysis which offers the possibility to observe relationships between sets of variables (Table 5).

In order to make a canonical correlation analysis the traits under study were divided into two sets of variables. The first set comprised determined (dependent) variables, i.e. meat tenderness assessed by means of the Warner-Bratzler shear force at each or at one of the terms under analysis. The other set included data determining the proportion of protein in the muscle tissue and the centrifugal drip on the gel. In some cases the other data set was extended by the values of $\mathrm{pH}_{1}$ and $\mathrm{EC1}$ (Table 5).

The analysis of the canonical correlation between tenderness (48 and $144 \mathrm{~h} \mathrm{pm}$ ) and the percentage of titin T1 and its degradation products in the muscle tissue (about $800 \mathrm{kDa})$ and centrifugal drip (3700-2400 kDa), and 38-36 kDa proteins (in the centrifugal drip and muscle tissue 48 and $144 \mathrm{~h} \mathrm{pm}$ ) revealed the highest correlation and determination coefficients $\left(C_{\mathrm{R}}=0.94^{* *} ; R_{\mathrm{C}}^{2}=0.89\right)(\mathrm{com}-$ parison I). This suggests that the degradation of these proteins significantly affects the meat tenderisation process.

A highly significant canonical correlation $\left(C_{\mathrm{R}}=0.94 * *\right)$ was also observed between shear force values after 48 and $144 \mathrm{~h} \mathrm{pm}$ and the proportion of centrifugal drip proteins with m.w. of $3700-2400 \mathrm{kDa}, 153 \mathrm{kDa}$ and $38-36 \mathrm{kDa}$, $\mathrm{pH}_{1}$ and $\mathrm{EC} 1$ values (comparison IV). A high value of the canonical correlation coefficient $\left(C_{\mathrm{R}}=0.88^{* *}\right)$ was also obtained by correlating the proportion of 3700,800 ,

Table 5 Values of selected canonical correlations and determinant coefficients between sets of analysed muscle traits

\begin{tabular}{|c|c|c|c|c|}
\hline \multirow[t]{2}{*}{ Comparisons } & \multicolumn{2}{|l|}{ Characteristics } & \multicolumn{2}{|l|}{ Coefficients } \\
\hline & Dependent (being explained) & Independent (explaining) & $\begin{array}{l}C_{\mathrm{R}} \text {-canonical } \\
\text { correlation value }\end{array}$ & $\begin{array}{l}R_{\mathrm{C}}^{2} \text {-determinant } \\
\text { coefficient value }\end{array}$ \\
\hline I & $\begin{array}{l}\text { Shear force values } 48 \text { and } \\
144 \mathrm{~h} \mathrm{pm}\end{array}$ & $\begin{array}{l}\text { Muscle tissue proteins: } 3700 \mathrm{kDa}, 800 \mathrm{kDa} \text { and cen- } \\
\text { trifugal drip proteins: } 3700-2400 \mathrm{kDa}, 38-36 \mathrm{kDa} \\
(48 \text { and } 144 \mathrm{~h} \mathrm{pm})\end{array}$ & $0.94 * *$ & 0.89 \\
\hline II & Shear force value $144 \mathrm{~h} \mathrm{pm}$ & $\begin{array}{l}\text { Centrifugal drip proteins: } 3700-2400 \mathrm{kDa}, 153 \text { and } \\
38-36 \mathrm{kDa}(144 \mathrm{~h} \mathrm{pm})\end{array}$ & $0.90 * *$ & 0.79 \\
\hline III & Shear force value $144 \mathrm{~h}$ & $\begin{array}{l}\text { Muscle tissue proteins: } 3700,800 \text { and } 105 \mathrm{kDa} \\
(144 \mathrm{~h} \mathrm{pm})\end{array}$ & $0.80 * *$ & 0.64 \\
\hline IV & $\begin{array}{l}\text { Shear force values } 48 \text { and } \\
144 \mathrm{~h} \mathrm{pm}\end{array}$ & $\begin{array}{l}\text { Centrifugal drip proteins: } 3700-2400,153 \text { and } \\
38-36 \mathrm{kDa}(48 \text { and } 144 \mathrm{~h} \mathrm{pm}) \text { and } \mathrm{pH}_{1} \text { and } \mathrm{EC} 1 \\
\text { values }\end{array}$ & $0.94 * *$ & 0.88 \\
\hline V & $\begin{array}{l}\text { Shear force values } 48 \text { and } \\
144 \mathrm{~h} \mathrm{pm}\end{array}$ & $\begin{array}{l}\text { Muscle tissue proteins: } 3700,800 \text { and } 105 \mathrm{kDa}(48 \\
\text { and } 144 \mathrm{~h} \mathrm{pm} \text { ) and } \mathrm{pH}_{1} \text { and } \mathrm{EC} 1 \text { values }\end{array}$ & $0.88 * *$ & 0.79 \\
\hline
\end{tabular}

\footnotetext{
** Coefficients statistically significant at $p \leq 0.01$
} 
$105 \mathrm{kDa}$ muscle tissue proteins marked 48 and $144 \mathrm{~h} \mathrm{pm}$ with both $\mathrm{pH}_{1}$ and $\mathrm{EC} 1$ values as well as shear force values 48 and $144 \mathrm{~h} \mathrm{pm}$ (comparison $\mathrm{V}$ ).

These results let us conclude that meat tenderness can be very accurately estimated 48 and $144 \mathrm{~h}$ pm on the basis of protein changes analysed using 1D electrophoresis and glycolysis process assessment criteria $\left(\mathrm{pH}_{1}\right.$ and $\left.\mathrm{EC} 1\right)$. The extended applicability of canonical variable analysis was also revealed by the assessment of relationships between the proportion of centrifugal drip proteins with an m.w. of $200 \mathrm{kDa}$ and $42 \mathrm{kDa}$ detected by using 2DE and the $\mathrm{pH}$ and EC values [38]. In this case the most significant $(p \leq 0.01)$ relationships were noted between percentage proportion of $200 \mathrm{kDa}$ protein $(3 \mathrm{~h} \mathrm{pm})$ and $\mathrm{pH}_{1}$ with $\mathrm{pH}_{2}\left(C_{\mathrm{R}}=0.98\right)$. Similar relationship was ascertained between the proportion of $42 \mathrm{kDa}$ protein $(48 \mathrm{pm})$ and $\mathrm{pH}_{2}$ with $\mathrm{EC}_{24}\left(C_{\mathrm{R}}=0.96\right)$ values. High canonical correlations $\left(C_{\mathrm{R}}=0.69-0.98\right)$ were also stated between proportion of above-mentioned centrifugal drip proteins and the shear force and cooking loss values $144 \mathrm{~h} \mathrm{pm}$; however, they were not statistically significant [38].

\section{Conclusions}

1. The process of meat tenderization in the porcine longissimus muscle is associated with degradation or release of muscle tissue proteins especially with m.w. of about 3700,105 and $38 \mathrm{kDa}$ as well as the changes of centrifugal drip proteins in m.w. ranges of 3700 $2400 \mathrm{kDa}$ and $38-36 \mathrm{kDa}$.

2. The high values of correlation coefficients ( $r=0.82 \div 0.94, p \leq 0.05$ ) between the percentage of native titin (T1) in the muscle tissue 48 and $144 \mathrm{~h} \mathrm{pm}$ and the $\mathrm{pH} 24$ and $48 \mathrm{pm}$ indicate close correlation between $\mathrm{T} 1$ degradation and the rate of glycolysis in muscles which was also linked with genotype of pigs.

3. The canonical correlation results point out that it is possible to predict meat tenderness with high probability (even $89 \%$ ) on the basis of selected protein changes analysed by means of electrophoresis and additionally, in some cases-by assessment of criteria of the glycolysis process $\left(\mathrm{pH}_{1}\right.$ and $\left.\mathrm{EC} 1\right)$.

\section{Compliance with ethical standards}

Conflict of interest All authors declare that they have no conflict of interest.

Compliance with ethics requirements This article does not contain any studies with human or animal subjects.
Open Access This article is distributed under the terms of the Creative Commons Attribution 4.0 International License (http://creativecommons.org/licenses/by/4.0/), which permits unrestricted use, distribution, and reproduction in any medium, provided you give appropriate credit to the original author(s) and the source, provide a link to the Creative Commons license, and indicate if changes were made.

\section{References}

1. Boles JA, Parrish FC Jr, Huiatt TW, Robson RM (1992) Effect of porcine stress syndrome on the solubility and degradation of myofibrillar cytoskeletal proteins. J Anim Sci 70:454-464

2. Bee G, Lonergan SM, Huff-Lonergan E (2004) Early postmortem $\mathrm{pH}$ influences proteolytic of cytoskeletal proteins during aging in porcine longissimus muscle. J Anim Sci 82(Suppl 1): 13

3. Belew JB, Brooks JC, McKenna DR, Savell JW (2003) Warner-Bratzler shear evaluations of 40 bovine muscles. Meat Sci 64:507-512

4. Bowker B, Gamble G, Zhuang H (2016) Exudate protein composition and meat tenderness of broiler breast fillets. Poult Sci 95:133-137

5. Carrera M, Losada V, Gallardo JM, Aubourg SP, Piñeiro C (2008) Development of an indirect $\alpha$-actinin-based immunoassay for the evaluation of protein breakdown and quality loss in fish species subjected to different chilling methods. Int J Food Sci Technol 43:69-75

6. Chang KC, da Costa N, Blackley R, Southwood O, Evans G, Plastow G, Wood JD, Richardson RI (2003) Relationships of myosin heavy chain fibre types to meat quality traits in traditional and modern pigs. Meat Sci 64:93-103

7. Choi YM, Kim BC (2009) Muscle fiber characteristics, myofibrillar protein isoforms, and meat quality. Livest Sci 122:105-118

8. Choi YM, Ryu YC, Kim BC (2006) Effect of myosin heavy chain isoforms on muscle fiber characteristics and meat quality in porcine longissimus muscle. J Muscle Foods 17:413-427

9. Davey CL, Gilbert KV (1968) Studies in meat tenderness 4. Changes in the extractability of myofibrillar proteins during meat aging. J Food Sci 33:2-7

10. Davey CL, Gilbert KV (1968) Studies in meat tenderness 6. The nature of myofibrillar proteins extracted from meat during aging. J Food Sci 33:343-348

11. D'Souza DN, Mullen BP (2002) The effect of genotype, sex and management strategy on the eating quality of pork. Meat Sci 60:95-101

12. Di Luca A, Elia G, Muellen AM, Hamill RM (2013) Monitoring post mortem changes in porcine muscle through 2-D DIGE proteome analysis of Longissimus muscle exudates. Proteome Sci 11:9. doi:10.1186/1477-5956-11-9

13. Di Luca A, Mullen AM, Elia G, Davey G, Hamill RM (2011) Centrifugal drip in accessible source for protein indicators of pork ageing and water holding capacity. Meat Sci 88:261-270

14. Fritz JD, Greaser ML (1991) Changes in titin and nebulin in postmortem bovine muscle revealed by gel-electrophoresis, western blotting and immunofluorescence microscopy. J Food Sci 56:607-610

15. Gagaoua M, Terlouw EMC, Boudjellal A, Picard B (2015) Coherent correlation networks among protein biomarkers of beef tenderness: what they reveal. J Proteom 128:365-374

16. Greaser ML, Boyer-Berri C, Kumazawa Y, Szalata M, Pospiech E (2000) Titin and tenderness. In: Proc 46th ICoMST, Buenos Aires, Argentina, pp 420-423 (4.I-L1) 
17. Grześ B, Pospiech E, Koćwin-Podsiadła M, Łyczyński A, Zybert A, Mikołajczak B, Iwańska E (2005) Analysis of the causes of meat quality variations of pigs with identical genotype. Pol J Food Nutr Sci 14/55(SI 1):59-63

18. Grześ B, Pospiech E, Koćwin-Podsiadła M, Łyczyński A, Krzęcio E, Mikołajczak B, Iwańska E (2010) Relationship between the polymorphism of myosin heavy chains and selected meat quality traits of pigs with different susceptibility to stress. Arch Tierz 53:65-72

19. Honikel KO (1987) Critical evaluation of methods detecting water-holding capacity in meat. In: Romita A, Valin C, Taylor AA (eds) Accelerated processing of meat. Elsevier Applied Science Publishers Ltd, London, pp 225-239

20. Hopkins D, Littlefield P, Thompson J (1999) The relationship between dissociation of actomyosin and tenderness. In: Proc 45th ICoMST, Yokohama, Japan, 4-P3, pp 250-251

21. Huff-Lonergan E, Mitsuhashi T, Parrish FC Jr, Robson RM (1995) Effect of postmortem ageing time, animal age, and sex on degradation of titin and nebulin in bovine longissimus muscle. $\mathrm{J}$ Anim Sci 73:1064

22. Huff-Lonergan E, Zhang W, Lonergan SM (2010) Biochemistry of postmortem muscle: lessons on mechanisms of meat tenderization. Meat Sci 86:184-195

23. Hwang IH, Park BY, Kim JH, Cho SH, Lee JM (2005) Assesment of postmortem proteolysis by gel-based proteome analysis and its relationship to meat quality traits in pig longissimus. Meat Sci 69:79-91

24. Iwanowska A, Grześ B, Mikołajczak B, Iwańska E, JuszczukKubiak E, Rosochacki SJ, Pospiech E (2011) Impact of polymorphism of the regulatory subunit of the $\mu$-calpain $(C A P N 1 S)$ on the proteolysis process and meat tenderness of young cattle. Mol Biol Rep 38:1295-1300

25. Jeleniková J, Pipek P, Miyahara M (2008) The effects of breed, sex, intramuscular fat and ultimate $\mathrm{pH}$ on pork tenderness. Eur Food Res Technol 227:989-994

26. Johnson RA, Wichern DW (2002) Applied multivariate statistical analysis. Prentice Hall, New Jersey, p 767

27. Jonsäll A, Johansson L, Lundström K (2000) Effects of red clover silage and RN genotype on sensory quality of prolonged frozen stored pork (M. Longissimus dorsi). Food Quality Pref 11:371-376

28. Koćwin-Podsiadła M, Krzecio E, Pospiech E, Łyczynski A, Antosik K, Grześ B, Zybert A, Sieczkowska H (2005) Selection of pork meat quality traits. Estimation of culinary and technological quality on the basis of measurements after slaughter. Fleischwirtsch Int 2:21-23

29. Koohmaraie M, Shackeleford SD, Veiseth E, Wheeler T (2002) Meat tenderness and muscle growth: is there any relationship? Meat Sci 62:345-352

30. Lametsch R, Roepstorff P, Bendixen E (2002) Identification of protein degradation during post-mortem storage of pig meat. $\mathrm{J}$ Agric Food Chem 50:5508-5512

31. Lametsch R, Karlsson A, Rosenvold K, Andersen HJ, Roepstorff P, Bendixen E (2003) Postmortem proteome changes of porcine muscle related to tenderness. J Agric Food Chem 51:6992-6997

32. Laville E, Sayd T, Morzel M, Blinet S, Chambon Ch, Lepetit J, Renand G, Hocquette JF (2009) Proteome changes during meat aging in tough and tender beef suggest the importance of apoptosis and protein solubility for beef aging and tenderization. $\mathrm{J}$ Agric Food Chem 57:10755-10764

33. Lee S, Nornan JM, Gunasekaran S, van Laack RLJM, Kim BC, Kauffman RG (2000) Use of electrical conductivity to predict water-holding capacity in post-rigor pork. Meat Sci 55:385-389

34. Lefaucheur L (2010) A second look into fibre typing-relation to meat quality. Meat Sci 84:257-270
35. Maltin C, Balcerzak D, Tilley R, Delday M (2003) Determinants of meat quality: tenderness. Proc Nutr Soc 62:337-347

36. Marino R, Albenzio M, Della Malva A, Santillo A, Loizzo P, Sevi A (2013) Proteolytic pattern of myofibrillar protein and meat tenderness as affected by breed and aging time. Meat Sci 95:281-287

37. Mikołajczak B, Pospiech E, Greaser ML, Iwańska E, Grześ B, Łyczyński A (2005) Low-molecular weight proteins of centrifugal drip as an indicator of meat tenderness. Ann Anim Sci Suppl 2:127-130

38. Montowska M, Pospiech E, Łyczyński A, Grześ B, Mikołajczak B, Iwańska E, Kapelański W, Bocian M (2009) Diversity of meat quality of heavy pigs with respect to the rate of post-mortem glycolytic and protein changes. Pol J Food Nutr Sci 59:315-323

39. Okumura T, Yamanda R, Nishimura T (2003) Survey of conditioning indicators for pork loins: changes in myofibrils, proteins and peptides during post mortem conditioning of vacuum-packed pork loins for 30 days. Meat Sci 64:467-473

40. Ouali A, Gagaoua M, Boudida Y, Becila S, Boudjellal A, HerreraMendez CH, Sentandreu MA (2013) Biomarkers of meat tenderness: present knowledge and perspectives in regards to our current understanding of the mechanism involved. Meat Sci 95:854-870

41. Park BY, Kim NK, Lee CS, Hwang IH (2007) Effect of fiber type on postmortem proteolysis in longissimus muscle of Landrace and Korean native black pigs. Meat Sci 77:481-491

42. Penny IF, Dransfield E (1979) Relationship between toughness and troponin T in conditioned beef. Meat Sci 3:135-141

43. Pommier SA, Murray A, Robertson W, Aalhus J, Gibson L, Sośnicki A, Klont R (2004) Effect of genetic on meat quality and sensory properties of pork. In: Proc 50th ICoMST, Helsinki, Finland, pp 544-547

44. Pospiech E, Szalata M, Van Lack RLJM, Sosnicki AA, Greaser ML (2001) Tenderness and protein changes of pork in relation to pig genotype and postmortem glycolysis phenotype. In: Proc 47th ICoMST, Kraków, Poland, 4-P, 8pp 258-259

45. Pospiech E, Szalata M, van Lack RLJM, Sosnicki AA, Greaser ML (2004) Tenderness and protein changes of pork in relation to pig genotype $\left(\mathrm{RN}^{-}\right)$and rate of postmortem glycolysis. Ann Anim Sci Suppl 2:257-261

46. Sawdy JC, Kaiser SA, St-Pierre NR, Wick MP (2004) Myofibrillar 1-D fingerprints and myosin heavy chain MS analyses of beef loin at $36 \mathrm{~h}$ postmortem correlate with tenderness at 7 days. Meat Sci 67:421-426

47. Sierra V, O'Reilly K, White A, Mullen A, Troy D (2005) Proteolytic fragments in bovine exudates as potential tenderization markers. In: Proc 51st ICoMST, Baltimore, USA, Th50, pp 113

48. Soriano Pérez A, García Ruiz A, Mariscal Contreras C, Cabezudo Ibáñez MD (2003) Separation and identification of sarcoplasmatic proteins from hams from three white pig crosses containing Duroc. Eur Food Res Technol 216:193-198

49. STATISTICA (data analysis software system), version 10. http:// www.statsoft.com. Accessed 2 Sept 2015

50. Szalata M, Pospiech E, Greaser ML, Łyczyński A, Grześ B, Mikołajczak B (2005) Titin and troponin-T changes in relation to tenderness of meat from pigs of various meatiness. Pol J Food Nutr Sci 14/55(2):139-144

51. Taylor RGH, Geesink VF, Thompson M, Koohmaraie M, Goll DE (1995) Is Z- disk degradation responsible for postmortem tenderization? J Anim Sci 73:1351-1367

52. Warren CM, Krzesinski PR, Greaser ML (2003) Vertical agarose gel electrophoresis and electroblotting of high-molecular-weight proteins. Electrophoresis 24:1695-1702

53. Watanabe A, Devine C (1996) Effect of meat ultimate $\mathrm{pH}$ on rate of titin and nebulin degradation. Meat Sci 42:407-413 
54. Wood JD, Brown SN, Nute GR, Whittington FM, Perry AM, Johnson SP, Enser MB (1996) Effects of breed, feed level and conditioning time on the tenderness of pork. Meat Sci 44:105-112

55. Wu W, Fu Y, Therkildsen M, Li XM, Dai RT (2015) Molecular understanding of meat quality through application of proteomics. Food Rev Int 31:13-28
56. Żelechowska E, Przybylski W, Jaworska D, Santé-Lhoutellier $\mathrm{V}$ (2012) Technological and sensory pork quality in relation to muscle and drip loss protein profiles. Eur Food Res Technol 234:883-889 